20. William Wernick: Functional dependence in the calculus of propositions. (Abstract 46-11-507-t.)

21. Hassler Whitney: The mappings of a 3-complex into a space with vanishing fundamental group. (Abstract 46-11-508-t.)

T. R. Hollcroft, Associate Secretary

\title{
THE NOVEMBER MEETING IN DETROIT
}

The three hundred seventy-third meeting of the American Mathematical Society was held at Wayne University, Detroit, Michigan, on Friday and Saturday, November 22-23, 1940. Ninety-five persons registered including the following sixty-nine members of the Society:

Max Astrachan, J. V. Atanasoff, W. L. Ayres, I. A. Barnett, E. F. Beckenbach' R. A. Beth, W. M. Borgman, H. K. Brown, R. S. Burington, R. V. Churchill, C. J· Coe, A. H. Copeland, Max Coral, C. C. Craig, J. M. Dobbie, M. J. Dunford, Ben Dushnik, W. D. Duthie, P. S. Dwyer, Samuel Eilenberg, A. G. Fleiger, K. W. Folley, Morris Friedman, H. H. Goldstine, V. G. Grove, O. G. Harrold, B. A. Hausmann, G. E. Hay, E., D. Hellinger, T. H. Hildebrandt, J. D. Hill, C. C. Hurd, F. B. Jones, Samuel Kaplan, Wilfred Kaplan, D. K. Kazarinoff, J. L. Kelley, E. D. McCarthy, A. V. Martin, D. D. Miller, E. W. Miller, D. C. Morrow, S. B. Myers, A. L. Nelson, C. J. Nesbitt, J. W. Odle, E. W. Paxson, E. C. Pixley, V. C. Poor, J. E. Powell, G. Y. Rainich, E. D. Rainville, C. E. Rickart, Arthur Rosenthal, J. B. Rosser, W. T. Scott, H. A. Simmons, B. M. Stewart, Otto Szász, Leonard Tornheim, A. W. Tucker, W. A. Vezeau, H. S. Wall, I. T. Weinberg, E. T. Welmers, K. P. Williams, L. A. Wolf, M. C. Wolf, J. W Zimmer.

The meeting opened Friday afternoon with a session for short papers, followed by an address by Professor J. B. Rosser of Cornell University entitled Many-valued logics. On Saturday morning Professor H. S. Wall of Northwestern University delivered an address under the title Some recent developments in the theory of continued fractions, and the meeting closed with a second session for short papers. Professor A. L. Nelson presided on Friday afternoon and Professor K. P. Williams on Saturday morning.

On Friday evening a dinner was held at the Belcrest Hotel with sixty-six persons attending. Professor A. L. Nelson presided at the dinner and Dean W. W. Whitehouse of Wayne University welcomed the Society in behalf of the institution. At the Saturday session Professor E. F. Beckenbach presented a resolution of appreciation to Wayne University and its Department of Mathematics for their hospitality. 
The titles of papers read at this meeting follow, papers 1-6 being read Friday afternoon and 7-10 Saturday morning. Papers 11-13, whose abstract numbers are followed by the letter $t$, were read by title. Paper 2 was read by Professor Miller, 3 by Professor Wall, 4 by Dr. Scott.

1. K. W. Folley: A property of a simply ordered set. (Abstract 47-1-23.)

2. Ben Dushnik and E. W. Miller: On the dimension of a partial order. (Abstract 47-1-89.)

3. W. T. Scott and H. S. Wall: Linear manifolds of Hausdorff means. (Abstract 46-11-504.)

4. W. T. Scott and H. S. Wall: A geometrical method in the theory of continued fractions. (Abstract 46-11-503.)

5. G. Y. Rainich: Postulates for fields. Preliminary report. (Abstract 47-1-7.)

6. A. W. Tucker: Barycentric mappings. (Abstract 47-1-110.)

7. F. B. Jones: Totally discontinuous linear functions whose graphs are connected. (Abstract 47-1-93.)

8. J. W. Odle: Non-separating and non-alternating transformations modulo a family of sets. (Abstract 47-1-102.)

9. Samuel Eilenberg: Linear measure and convexity. (Abstract 471-22.)

10. H. A. Simmons: Maximum numbers associated with a symmetric Diophantine equation in $n$ reciprocals. (Abstract 47-1-86.)

11. A. N. Milgram: Extensible and inextensible decompositions. Preliminary report. (Abstract 47-1-96-t.)

12. M. M. Day: Reflexive Banach spaces which cannot be made uniformly convex. (Abstract 46-9-396-t.)

13. M. M. Day: Some more uniformly convex spaces. (Abstract 46-11-486-t.)

W. L. Ayres, Associate Secretary 